\title{
Class, State and Industrialisation in South Korea ${ }^{1}$
}

\section{Clive Hamilton}

The question we address here is how industrial capital became the dominant economic force in South Korea in the post Second World War period. Industrial development in South Korea (hereafter Korea) has been carried out mostly by private capital, ${ }^{2}$ although much of my argument concerns the ways in which the state has influenced the form and pace of accumulation. The essential premise is that the explanation of how industrial capital becomes the driving force of society lies at the very centre of any understanding of Third World industrialisation. It raises two fundamental questions. First, how is the social surplus product generated - under what social relations (feudal, capitalist, petty proprietorship) and using what productive forces (land, labour, fixed capital, technology)? Second, how is the social surplus product, once produced, used? Is it consumed luxuriously, remitted overseas, reinvested in industry, trade or agriculture, or taxed by the state? The two questions are intimately related.

The state appears as a prime mover at every stage of class formation in Korea. There is no attempt here, however, to develop a theory of the state, not only because this would be very difficult, but also because I am not convinced that it is valid to do so. Instead I interpret the state in terms of the mode of reproduction of society or the process of accumulation. The policies of the state should be seen as both reflecting and influencing the class structure. The history of modern Korea tells us that the state is not necessarily the instrument of a particular class (although at times it has been), but it remains true that

\footnotetext{
1 I would like to acknowledge the valuable comments and criticisms of David Evans, Jon Halliday, Richard Luedde-Neurath and Gordon White.

2 In 1963 private enterprise produced 87 per cent of non-agricultural GDP: the same figure applied in 1972. In the lat ter year it accounted for 85 per cent of valuc-added in manufacturing and was outweighed by public enterprise only in electricity, water and sanitation, and finance. However. public enterprise absorbed about 30 per cent of total investment over the period 1962-73. All figures are trom Jones and SaKong [1980:148-50].
}

at any time the state is thrown up in the process of class struggle.

\section{The Process of Primitive Capitalist Accumulation}

Japanese colonial rule (1910-45) had a profound effect on the class structure of Korea, shaking it out of the stagnation of the Yi dynasty. The political dominance of the old ruling class - the monarchy, bureaucracy and nobility - was swept away, and its economic power was weakened as the Japanese acquired a large proportion of cultivated land. Tenancy greatly increased and agriculture - which provided Japan with a large exportable surplus - became even more firmly based on the landlord-tenant relationship. ${ }^{3}$ Although capitalist social relations were not introduced into agriculture on a wide scale, production became far more market-oriented, and the traditional self-sufficiency and village insularity were destroyed forever. There was, however, a remarkable growth of capitalist industry during the $1920 \mathrm{~s}$ and 1930s, supplied by a glut of farmers-turned-proletarians driven from the land by rural pauperisation. This industry was overwhelmingly dominated by Japanese capital, but a significant class of indigenous capitalists did emerge, mainly in trade and small-scale industry.

Although capitalist social relations thoroughly penetrated Korean society during the Japanese period, the economy remained predominantly agricultural and based on landlord-tenant relations. Precapitalist forms continued to dominate immediately after the war. The 1950s, however, saw a further radical transformation of Korean society, one which laid the foundation of the industrial growth of the 1960s. This was a deepening of primitive accumulation whereby capitalist social relations became the dominant social form, politically and economically. Although it was not until well into the 1960s that the

3 This is the briefest summary of the much more detailed discussion in chapter 2 of Hamilton [1983], from which the argument of this paper is extracted.

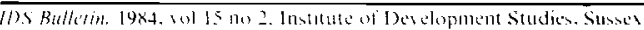


output of capitalist manufacturing and service industries began to outweigh that of agricultural peasant-proprietors, it was clear by the end of the 1950s that capitalism had taken hold as the irreversible moving force in South Korean society.

This process of primitive accumulation separated labour from the land and reconstituted it as an industrial working class. It simultaneously transformed the physical and social basis of money-making from agriculture to industry, converting rentier assets into capital which multiplied through productive investment. ${ }^{4}$ The importance of the process lay not in the amassing of fortunes by individuals or firms, but in the creation of conditions in which capital could be accumulated through industrial production using wage-labour. This transition came about in two broad phases; the transformation of rentier assets into commercial capital in the 1950 s and the transformation of commercial into industrial capital in the 1960s. This, of course, is a generalisation - in the 1950s, significant industrial growth took place - but we will show it to be a reasonable one reflecting the broad trends of accumulation in South Korea.

\section{Phase I: the transformation of landed assets into merchant capital in the $1950 \mathrm{~s}$}

This came about in response to both repulsion from the land and attraction to commerce. The former was a result of the land reform, which was promulgated in its final form in March 1950. It was based on the principle of land-to-the-tiller and outlawed tenancy. Along with land distributed by the US Army Military Government (AMG) and land sold to tenants in anticipation of land reform, the law within a couple of years saw the redistribution of the great majority of tenanted land in South Korea. The law set an upper limit of about three hectares per household and although there were some exemptions and cheating, the reform did succeed in transferring the ownership of the vast bulk of agricultural land to the cultivators. Between 1945 and 1965 the proportion of farm households which wholly owned their land rose from 14 to 70 per cent, and the proportion of pure tenants fell from 49 per cent to 7 per cent [Ban et al 1980:286]. Consequently, agrarian social relations changed profoundly and the rural power of the landlord class was eliminated.

What precise effect did the land reform have on landlords? First, it confirmed the decline in their political and economic power. Land ownership had already become less attractive because rents, traditionally very high, were more difficult to collect from

\footnotetext{
${ }^{4}$ Since in post-war Korea agriculture was not based on capitalist production relations it is not strictly accurate to talk of agricultural capital' and 'rentier capital', thus the 'transformation of capital'. The essential transformation is of the mode of production.
}

an increasingly truculent peasantry and had been reduced by the state's grain collection policy. The Land Reform Act decreed that former tenants were to pay for their land 1.5 times the normal annual output of the main crop. payable over five years to the government. Landlords were to receive the equivalent in government bonds (whose value was to be expressed in terms of rice). However, since the government often did not redeem the bonds on time and since most landlords could not use them as collateral on business loans, the market price of the bonds fell sharply.

Ban et al conclude that landlords received compensation equivalent to around $15-25$ per cent of their former land assets [1980:290]. The difference accrued partly to the former tenants and partly to the government. Though many landlords went bankrupt in the early 1950s [Pak and Gamble 1975:33], these tended to be smaller owners who had not dissociated themselves from the land in advance. More land was sold privately by landlords to tenants in the 1945-5 I period than was appropriated under the land reforms [Ban et al 1980:286; also Pak and Gamble 1975:32] and was disposed of on terms much more favourable to the landlord. Moreover, the bonds of the dispossessed landlords were exchangeable for industrial facilities formerly owned by the Japanese, and several of today's large industrial concerns emerged in this way. However, it was not always the landlords who acquired the vested property this way for many bonds were sold on the market to entrepreneurs, for prices between 30 and 70 per cent of their face value. These latter were often technical or managerial employees of the same companies under the Japanese. The factories were often sold at prices well below their actual worth and financed by low-interest government loans, frequently in return for political favours. Jones and SaKong observe that the attempt at 'converting landlords into capitalists is generally held to have been a failure' [1980:35-61].

The evidence on the direct conversion of landlords into merchants and industrialists is scarce. Jones and SaKong's argument applies specifically to the scheme of exchanging assets in land for assets in Japanesebuilt factories through bonds. But this does not mean that landlords could not find other paths into the business world. If, despite the confiscatory element of the land reform, many rich landlords were left still wealthy after disposal of their land, they must have found an alternative place to put their capital. In the $1950 \mathrm{~s}$, after the end of the war, opportunities for profitable investment arose both in commerce, particularly importing, and in import-substituting industrial production. From the viewpoint of the accumulation of capital the important point, however, is not whether landlords were converted into capitalists but that asset-holding and investment in 
land declined while commercial accumulation accelerated. Even so, it is worth noting that the wealthier landlords formed a disproportionate number of the capitalists who financed the industrial growth of the 1960s and 1970s. A survey of manufacturing firms in 1976 found no less than 47 per cent of entrepreneurs' fathers had been 'large-tomedium landowners' [Jones and SaKong 1980:228].

The South Korean industrial economy suffered extensive damage in the world war and again during the civil war of 1950-53, and factories were slow to return to capacity. Moreover, the north, now cut off, had produced most of the peninsula's metallic and chemical products and electric power. All this led to severe shortages of manufactured (particularly consumer) goods throughout the late 1940s and 1950s, which provided lucrative opportunities, and subsequently led to widespread charges of profiteering. The basis for accumulation through trade lay in foreign exchange allocation and US aid. No systematic study has been made of this period and evidence is almost wholly anecdotal [for some examples, see Jones and SaKong 1980:272-3].

Kyong-Dong Kim has analysed the development of the chaebol (family-based industrial conglomerates) in the 1950 s as a process of political favouritism allowing windfall profits on commercial deals connected to foreign aid [1976:468]. For instance, in 1952 the Rhee administration illegally allocated three million dollars of foreign exchange earned through tungsten exports to 40 private firms. The funds were used to import grains and fertilisers which, when sold at monopoly prices and taking advantage of the discrepancy in foreign exchange rates, earned enormous profits, some of which flowed to R hee's Liberal Party. Similar gains were made by cement-producing firms which also imported quantities of cement that were sold at vastly inflated prices responding to high demand.

In markets where imported goods fetched very high premiums, foreign exchange was a precious commodity. Since exports were relatively small, the source of most foreign exchange was aid. According to Byun and $\mathrm{Kim}$ 'it was a privilege to get a foreign exchange allocation since import itself guaranteed profitable opportunities because of the general shortage in every kind of consumer good' [1978:10]. Preference in allocation was given to exports (mainly of agricultural and mineral products) and domestic producers dependent on imports of capital goods. Loans for these industries accounted for 45 per cent of total imports in the 1945-61 period, and Byun and Kim conclude that 'this access to loans rather than production itself must have been the backbone of profitable capital accumulation at that time' [1978:10]. Many traders were also able to take advantage of the multiple exchange rate system which, when combined with an official exchange rate well below the market rate, acted to subsidise the cost of imports from government coffers [Byun and Kim 1978:11].

US aid was essential to this process. Dollars and imported materials flowed to selected businesses, and whether or not these resources were used to add value domestically or were simply resold at a premium, the mark-up could be prodigious. Access to productive inputs which were limited by the shortage of foreign exchange guaranteed some sort of monopoly over the sale of goods produced with them. Not only could big profits be made through access to dollars or imports directly, but the flood of US army supplies after each war permitted individuals with a little capital, political influence or well-placed contacts to build fortunes. This was augmented later by 'the hundreds of millions of dollars' worth of surplus army material [which] permitted some practitioners of "buy-and-sell" to become established merchants' [Sung-Jae Koh in Park et al 1980:373]. Later, when aid was allocated for specific projects, collusion and political favouritism in the bidding for government and US military contracts was a further source of easy accumulation. This method is said to have led to the emergence of the 'Five Men' of the construction industry [Kim 1976:469]. The close relationship between the state and segments of private capital was one of the most important sources of accumulation.

Though the dominant trend during the period was the emergence of capital in merchant form, we should also recognise the considerable import-substituting growth which occurred in the 1950s. The real gross fixed capital stock grew at an average annual rate of 5.1 per cent between 1953 and 1962 [Hong 1979:20-1, Table 2.6]. Moreover, although superprofits could be had through access to foreign exchange and import licences, the goods so obtained were often used in productive activities which contributed to industrial accumulation. At least 45 per cent of imports in the 1945-61 period went to domestic industrial concerns. Even so, the dynamism of commerce in this period is demonstrated by Byun and Kim in their study of the 'Fifty Groups', South Korea's 50 most powerful industrial groups consisting of over 500 firms, nearly 60 per cent of which are in manufacturing [Byun and Kim 1978]. Of the 50 groups, 31 were established in the period under consideration, 1945-61 (13 in 1945-52, 18 in 1953-61). Of these 31, no fewer than 11 began business in foreign trade [Byun and Kim 1978]. It might be objected that the official figures, so far as they are accurate, show that wholesale and retail trade in fact grew a little less fast than manufacturing in 1953-60 [Economic Statistics Yearbook 1967:10-11]. But a very large part of the trade being carried on in 
South Korea at this time was not only immeasurable but illegal, and probably outside official statistics.

There is no question, however, that a great deal of import-substituting production began in the 1950s and that this represented the growth of industrial capital. The conditions for this were excellent. First of all, there were a great number of factories built by the Japanese which passed into Korean hands. Nor should we ignore the significant development of Korean-owned industry in colonial times, most of which continued to operate and expand after the war [Jones and SaKong 1980:28 give the details]. Thirteen of the future 50 groups pre-dated the world war [Byun and Kim 1978:8]. Through the stimulus of shortages and abetted by government policy, import substitution in the 1950s emphasised basic consumer industries such as textiles, flour milling and sugar refining. From 1953 to 1961 , mining and manufacturing grew at an average annual rate of 12.2 per cent [Economic Statistics Yearbook 1970:50]. Although this new production did replace potential imports, there was still an increase in import dependence in many manufacturing sectors during the $1950 \mathrm{~s}$, including processed food, clothing, printing, and almost all heavy, chemical and machinery sectors (but not textiles, wood products and paper) [Suh 1975: Tables 5-1 and 5-2].

Nevertheless the government had taken certain measures to encourage the development of domestic manufacture. The multiple exchange rate helped and so did high tariffs on both aid and non-aid financed imports. The overvalued exchange rate was offset by a system of tariffs whose rates rose in accordance with the degree of competitiveness of the imports with domestic production (but with very heavy rates levied on luxury goods) and were low on necessary imports of raw materials and capital goods. A system of tariff exemptions helped channel imports at reduced cost to selected domestic industries [Hong 1979:45-9; Suh 1975: 198-9]. Undesired competition from imports was further discouraged by quotas and tax exemptions, and domestic industrial firms had access to bank loans at cheap rates for expansion. These measures, which aimed at expanding profits and hastening accumulation in domestic enterprise, were the more effective in that their impact was largely concentrated on the bigger companies, the emerging chaebol.

By the end of the 1950s it was becoming clear that the economic system that had overseen the decline of the landed rentier and the rise of the capitalist could not be sustained. The economy was a derivative one; industry and agriculture were dependent on imports for survival. The value of imports was at least 10 times that of exports, and only US aid kept the economy afloat [Hong 1979:46]. The significance of this had been brought home through the cuts in aid in 1958-60 which were accompanied by falling growth rates. The problem of the foreign exchange gap began to exercise the minds of economists and politicians as it became evident that US aid would not last very many years. Social stability rested on imports and aid. But although these factors suggest why a change in the economic structure became necessary for future development, it does not explain how that change came about.

\section{Phase II: the transformation of commercial into industrial capital in the $1960 \mathrm{~s}$}

The transition was launched by the student revolution of 1960 which toppled the corrupt Rhee regime that had so transformed society from its agricultural base. The revolt might be seen as a product of the political strains brought about by the inability of merchant capital to provide for the needs of the people. As if to confirm our argument about the dominance of commercial capital in the 1950 s and the methods by which it was created, the anger of the populace was directed mainly against profiteers, parasites, the corrupt and the abusers of authority. The new military government responded to popular demands for retribution and passed a special law for dealing with illicit wealth accumulation, designed to punish those who "accumulated wealth illicitly by taking advantage of their positions of power'.

The latter was defined to cover those who had made illicit profits from foreign exchange allocation, contracts for public works and commodity supply, cheap bank loans, tax avoidance and overseas transfer of wealth. The Park government arrested most of Korea's leading businessmen, and stood poised to confiscate their assets. A deal was subsequently struck, reflecting the changed economic emphasis of the new administration, whereby criminal charges would be dropped if the businessman agreed to build factories and donate them to the state. According to Jones and SaKong [1980:278], Park ushered in a new phase in which the unproductive 'zero-sum activity' of the 1950 s was largely replaced by 'positive-sum activity'. The illicit wealth acccumulation episode established a pattern "whereby substantial assistance was given to established businessmen who proved themselves capable of initiating new manufacturing and export activity. 5

Just as the transition from land rent to commercial business came about under forces of repulsion and

\footnotetext{
${ }^{5}$ One of the comments to emerge consistently in the interviews by Jones and SaKong [1980: appendix A] with small and medium businessmen is the belief that the 1950s were more corrupt, and that in the 1960s government had become 'more efficient and more impartial', less subject to favouritism and more supportive of business.
} 
attraction, so it was in the transformation of merchant into industrial capital. The repulsion of capital from its old commercial circuit was due to the elimination of the opportunities to make big profits simply through trade and access to foreign exchange. In large measure this was due to the fact that the military government, unlike its predecessor, was not initially dependent on donations from the wealthy, and by the time civilian rule and elections came a round industrial capital was sufficiently well-organised to deliver strong support to the Park government.

As the $1960 \mathrm{~s}$ progressed it became increasingly difficult to multiply capital simply through access to foreign exchange, aid funds and government favour. These things continued to exist but the profits attached to them were increasingly tied to productive activity, the adding of value. The ability to import through access to foreign exchange, which had been so lucrative in the $1950 \mathrm{~s}$, was made more and more dependent on matching productive activity. The export-import link system, introduced in 1962, (discontinued in 1964 but reintroduced in 1966) gave domestic manufacturers who could achieve export success access to import licences for the most restricted, and most rewarding, imported commodities. ${ }^{6}$ The impact was to encourage the growth through exports of industries whose profit margins would not otherwise have led to such expansion. While the plethora of export promotion policies introduced in the 1960 s can be seen in this light, the value of the export-import link system was that it encouraged productive activity by making available funds which would otherwise have filled the pockets of merchants. This was not the only scheme to use the scarcity of foreign exchange to provide incentives for productive activity. The wastage allowance, which permitted exporting firms to import intermediate inputs over and above the technical requirements of production, provided another source of profit tied to expansion of value-added.

Given the import substitution of the 1950 s, it became easier in the 1960 s to limit severely imports of the consumer goods which had been such bount iful profitmakers for traders. The political climate made it feasible to clamp down hard on the import of luxury goods. This was achieved not only by simple prohibition but also by the series of big devaluations of the won which followed the ousting of Rhee. By making imports much more expensive they removed much of the excess demand for imports which had dominated the 1950s.

\footnotetext{
The export-import link system had also operated between 1951 and 1955. but since exports were so small in that perind and such exports as there were tended to be primary produets, it was not an effective inducement to industrial expansion.
}

In keeping with the military-turned-civilian government's productionist bias, everywhere bureaucratic discretion, which has been a pillar of Korean industrial development, has favoured manufacturing expansion over commercial activity. Industrial promotion policies have been the mark of a government that measures its success by growth statistics. In the taxonomy of Jones and SaKong, only one of the main zero-sum activities of the 1950s domestic and foreign credit - was not eliminated in the transitional period [1980:273]. But even here excess profits could be obtained by access to cheap bank credit only on condition that the loan be used for industrial expansion. The government had assumed control of the commercial banks in the 'illicit fortunes' confiscations of 1961 , and this control over finance was used to promote industrial growth by lengthening the time-spans of loans so that industrial projects with long gestation periods could secure finance. The importance of bank lending in the economy was enhanced by the interest rate reform of September 1965 which attracted a great flow of deposits into banks and out of the short-term curb market.

The US role in all of this was crucial. From the mid1950s, US aid officials and US government policy had been pressing hard for the more efficient and productive allocation of aid funds. The US urged the Rhee government to build up the economic strength of the country so that its development would be less reliant on US aid. A large part of the explanation of the withdrawal of US support for Rhee lay in his unwillingness to embrace their view of Korea's economic future. Certain changes also occurred in the early 1960s which all but eliminated aid as a source of commercial accumulation. First, the volume of aid declined, both in absolute value and relative to national income. ${ }^{7}$ Second, in the 1950 s aid dollars had been sold to selected importers at an official exchange rate which was about half of the estimated parity rate during 1953-61, and this was the source of windfall profits [Hong 1979:138]. The exchange rate reforms of the early 1960s largely eliminated this gap. Third, a growing proportion of US aid took the form of PL 480 surplus agricultural commodities (rising from an average of 11 per cent in 1959-61 to 38 per cent in 1962-64). Consisting almost wholly of wheat and cotton (especially after 1959), these flowed directly into the flour-milling and textile industries [Hong 1979:137, Table 6.8]. Finally, as the diminishing volume of aid was replaced by foreign loans and

\footnotetext{
Total aid (undeflated) averaged US $\$ 325 \mathrm{mn}$ per annum in 1956-58. $\$ 222 \mathrm{mn}$ in $1959-61$ and $\$ 199 \mathrm{mn}$ in 1962-64. and these represented respectively around 14 per cent. 8 per cent and 6 percent of Korean GNP [Hong 1979:135]

8 The 1966 foreign capital inducement law empowered the planning minister to approve foreign capital inflows if they contributed to export production or the development of key industries [Hong 1979:142].
} 
investment, the government could itself carefully regulate the inflow of finance. ${ }^{8}$

\section{Conclusion}

This study of the development of the classes of Korean capitalism has a recurring theme: primitive accumulation and the rise of industrial capital has been as much a political process as an economic one, In the re-ordering of agrarian social relations and the ruin of the landlord, in the promotion and expansion of commercial capital and then its change into industrial form, in the provision of a vast supply of wage workers, and in the protection of industrial capital from the ravages of debt, the state has played a fundamental role, At first land reform, distribution of aid, allocation of import licences and loans, then the confiscation of illicit fortunes, curbing corruption, tying profitability to productive activity through a battery of policies, cracking down on speculative and short-term capital, and sponsoring massive ruralurban migration, each has been instrumental in establishing the primacy of industrial accumulation. This is not to claim that all of these measures were deliberately taken to achieve this dominance, nor to claim that the state was a neutral decision-maker immune to the influence of the forces it was helping to create. There is no question, however, that the historical process which gave to the Korean state a large degree of autonomy from particular class interests was critical in the ascendancy of industrial accumulation.

\section{References}

Ban, Sung Hwan, Pal Yong Moon and Dwight Perkins, 1980 , Rural Development, Council on East Asian Studies, Harvard University Press, Cambridge (Mass)

Byun, H. Y. and S. H. Kim, 1978, 'Modernisation of private enterprises in the Republic of Korea: a study of the Fifty Groups' development pattern', Joint Research Program Series no 7, Institute of Developing Economies, Tokyo

Economics Statistics Yearbook, Bank of Korea, Seoul

Hamilton, C., 1983, Capitalist industrialisation in the Third World: revelations from South Korea, unpublished DPhil thesis, University of Sussex

Hong, Wontack, 1979, Trade, Distortions and Employment Growth in Korea, Korea Development Institute, Seoul

Jones, Leroy and II Sa Kong, 1980, Government, Business and Entrepreneurship in Economic Development: the Korean case, Council on East Asian Studies, Harvard University Press, Cambridge (Mass)

Kim, Kyong-Dong, 1976, 'Political factors in the formation of the entrepreneurial elite in South Korea', Asian Survey, vol 16 no 5

Pak Ki-Hyuk and Sidney Gamble, 1975, The Changing Korean Village, Royal Asiatic Society (Shin-Hung Press, Seoul)

Park, Sung-Jo, Taiwhan Shin and Ki Zun Zo (eds), 1980 , Economic Development and Social Change in Korea, Campus Verlag, Frankfurt

Suh, Suk Tai, 1975, 'Import substitution and economic development in Korea, Working Paper 7519, Korea Development Institute, Seoul 